Research Article

\title{
Relationship between Vaginal Sialidase Levels with Threatened of Preterm Labour
}

\section{Hubungan antara Kadar Sialidase Vagina dengan Ancaman Persalinan Prematur}

\author{
Bambang Sulistyo, Najoan N Warouw, Eddy Suparman \\ Department of Obstetrics and Gynecology \\ Faculty of Medicine Universitas Sam Ratulangi/ \\ Prof. Dr. R.D. Kandou General Hospital \\ Manado
}

Abstrak

\begin{abstract}
Objective: To investigate the association between vaginal sialidase levels and threatened of preterm labor.

Methods: A cross sectional study design was used. Subjects were divided into two groups; the first group were pregnant women with threatened of preterm labour, whereas the second were preterm pregnant women in Prof. Dr. R.D. Kandou Manado hospitals and network hospitals, during the period between August 2016 and October 2016. Data were analyzed with SPSS version 20 to see the significancy levels.

Results: From the 16 pregnant women with threatened of preterm labor and 16 pregnant women with preterm pregnant, the statistical $t$ test showed that there were significant differences average level of sialidase vagina between the threatened of preterm labor and preterm pregnant group $(\mathrm{p}=0.000)$.

Conclusion: There is a relationship between the incidence threatened of preterm labor with vaginal sialidase levels.

[Indones J Obstet Gynecol 2018; 6-1: 23-27]

Keywords: bacteria, threat of preterm labour, vaginal sialidase
\end{abstract}

Tujuan: Untuk melihat adanya hubungan antara kadar sialidase vagina dengan ancaman persalinan prematur.

Metode: Penelitian ini adalah studi potong lintang, dilakukan pada kelompok ibu hamil dengan ancaman persalinan prematur dan ibu hamil prematur di RSUP Prof. Dr. R.D. Kandou Manado dan RS jejaring, mulai Agustus 2016 sampai dengan Oktober 2016. Data dianalisis dengan SPSS versi 20 untuk melihat tingkat kemaknaannya.

Hasil: Dari 16 ibu hamil dengan ancaman persalinan prematur dan 16 ibu hamil dengan hamil prematur, pada uji statistik t-test menunjukkan bahwa ada perbedaan yang bermakna kadar ratarata sialidase vagina antara kelompok ancaman persalinan prematur dan kelompok hamil prematur $(p=0,000)$.

Kesimpulan: Ada hubungan antara kejadian ancaman persalinan prematur dengan kadar sialidase vagina.

[Maj Obstet Ginekol Indones 2018; 6-1: 23-27]

Kata kunci: ancaman persalinan prematur, bakteri, sialidase vagina

\section{INTRODUCTION}

Preterm labour remains an important cause of perinatal morbidity and mortality in developing countries. Preterm labour, especially those that occur before 34 weeks' gestation, leads to $3 / 4$ of overall mortality in neonates. The infant mortality rate of preterm and very preterm (gestational age $<32$ weeks) were 15 and 75 times higher than babies born aterm. Premature infants who survive will suffer serious morbidity short terms, such as respiratory distress syndrome, bronchopulmonary dysplasia, interventricular haemorrhage, retinopathy of prematurity result, whereas at the long term, such as developmental disorders and neurological disorders. The morbidity rate may be reduced by doing a prevention of preterm birth procedure such as early and accurate predictions, eliminate the risks and delay the onset of labour to do an intervention using various treatments such as tocolytic, corticosteroids, and antibiotic prophylaxis. One pathogenic process of premature labour is inflammation. ${ }^{1}$

Pregnancy (gravidity) is called at term if between $37-<42$ weeks since the beginning of the last 28 days menstrual cycle. According to WHO preterm labour is labour that occurs between the ages of 20 weeks to about 37 weeks of the beginning of the last menstrual cycle (28 days). ${ }^{2}$ In this context, developing countries have a higher incidence rate than developed countries. For the past 10 years, the incidence of BBLR hospitals nationwide was $27.9 \%$. Approximately, the birth 
rate in Indonesia is 5000.000 people per year, which could be calculated into infant mortality $56 / 1000$ live births, equal to more or less 280,000 per year. ${ }^{3}$

Approximately $50 \%$ of the causes of preterm labour are unknown, and about $12.5 \%$ of preterm birth was preceded by premature rupture of membranes, wherefore, mostly due to factors of infection. ${ }^{4}$ One basic pathogenesis of preterm labour is inflammation. From all of the etiopathogeneses, the most common cause of preterm labour is an infection, which means that the process of infection in the vagina and cervix (genital tract) may damage the vaginal mucosa and cervical barrier, thus bacteria can reach the uterus. In the vaginal mucosa consists of mucus glycoproteins (mucin) containing an antibacterial such as IgA, lactoferrin, and lysosomes. All this is contained in the surface epithelium of the vagina and cervix. In state of infection, mucus enzymes, digesting enzymes, were produced by bacteria such as sialidase, $\beta$-Galactosidase, $\beta$-N-Acetylhexosaminidase, a mucinous enzyme. This sialidase enzyme that can damage the vaginal mucosa and cervix into the uterus resulted in bacteria. Sialidase enzyme is also elevated in bacteria that colonise in the vagina. Sialidase produced by bacteria would lower the immunity of the vagina. Sialidase may potentially lower vaginal mucosal protective factors such as mucin, cytokines, immunoglobulins, antimicrobial molecules, and immune cell receptors. ${ }^{5}$

Howe and Wiggins reported that the levels of vaginal sialidase could be used to detect the presence of genital infections as well as the possibility of preterm labour in pregnant women. In this research, it concluded that the increased enzyme sialidase (BSM, $\mathrm{p}<0.005) .{ }^{6}$

To this date, studies regarding have never been done at the department of Prof. Dr. R.D. Kandou Manado. This study is aimed to investigate the predictors of preterm labour at Prof. Dr. R.D. Kandou Manado.

\section{METHODS}

This was across-sectional study between the threatened of premature labour group and the premature pregnant group that conduct at RSUP Prof. Dr. R.D. Kandou Manado and its network hospital. Generally, this research aims to comprehend the connection between vaginal sialidase levels with the threatened of premature labour.

The research was conducted at RSU Prof. Dr. R.D. Kandou and its hospital networks in Manado from August 2016 to October 2016. From the sample, based on data collection, it obtained a total sample of 16 groups with the threatened of preterm labour and 16 groups of preterm pregnant women who meet the inclusion and exclusion criteria. Examination of a vaginal swab to detect the enzyme sialidase vagina.

Subjects were all pregnant patients under threatened of preterm labour and preterm pregnant women with normal pregnancies who meet the inclusion and exclusion criteria. The sample is part of a selected population, which includes all pregnant patients prematurely with the threatened of preterm labour and preterm pregnant with normal pregnancies were examined at the obstetric department of Prof. Dr. R.D. Kandou Manado and its hospital networks. The research subject took a vaginal swab for a sample to be determined through the rejection and acceptance criteria.

A set of acceptance criteria for the research sample were patients agreed to participate in the study, patients with prematurity (gestation less than 37 weeks) with infants $<2,500$ gram, mother who threatened preterm labor (pregnancy less than 37 weeks) with infants $<2,500$ gram, possess a valid information when the day her last menstrual period (LMP), and single-fetus pregnancies either ultrasound or physical examination.

Whereas, the rejection criteria for the research sample were patients who did not know their last menstrual period (LMP), pregnant patients with gestational multiple, polyhydramnios, congenital anomalies of the fetus, pregnant patients with anaemia: $\mathrm{Hb}<10 \mathrm{~g} / \mathrm{dl}$, has a systemic infection, diabetes, hypertension, liver disease, kidney, and malignancy, suffered an amniotic premature rupture membrane.

Patients who met the inclusion criteria and then examined the levels of enzyme sialidase vagina by way of vaginal swab results for vaginal swab is inserted into the transport tube and then examined using neuraminidase kit. Quantitative Examination 
of the vagina with sialidase levels spectrophotometrically, a sensitivity of $1.0 \mathrm{pg} / \mathrm{ml}$ using a human sandwich kit neuraminidase (NEU) Elisa kit catalogue: MBS720861.

Each patient would be enrolled in this research adjusted to the principles of research ethics, that every pregnant woman premature enrolled in this study will be conducted counselling before hand with an explanation of the purpose and objectives of this research. If you agree, then the candidate must sign an agreement research study.

Analysis and data processing were carried out by the authors under statistics supervisor. Meanwhile, the data collection will be carried out by the researcher. It is executed both manually and computerised by using the software program Statistical Product and Service Solution (SPSS) for Windows version 20.

\section{RESULTS}

After effectuating research in RSU Prof. Dr. R.D. Kandou Manado and hospital networks in Manado from August 2016 to October 2016. This study has examined 16 pregnant women with threatened of preterm labor and 16 pregnant women with premature pregnancy.

The results of this study are presented below.

Table 2. Data Distribution of Vaginal Sialidase levels

\begin{tabular}{ccc}
\hline \hline $\begin{array}{c}\text { Parameter } \\
\text { Sialidase Vagina } \\
\text { (ng/ml) }\end{array}$ & $\begin{array}{c}\text { Premature } \\
\text { Gestation } \\
\text { (n=16) }\end{array}$ & $\begin{array}{c}\text { Preterm Labour } \\
\text { Threat }(\mathbf{n = 1 6})\end{array}$ \\
\hline Mean & 245.46 & 710.16 \\
Minimum & 109.83 & 22.76 \\
Maksimum & 472.44 & 1432.43 \\
p Normalitas & 0.389 & 0.104 \\
\hline \hline
\end{tabular}

Table 3. Results of Relations Vaginal Sialidase Levels

\begin{tabular}{cccc}
\hline \hline \multirow{2}{*}{ Parameter } & \multicolumn{3}{c}{ Sialidase Vagina Levels $(\mathbf{n g} / \mathbf{m l})$} \\
& Mean & SD & p \\
\hline $\begin{array}{c}\text { Threatened of Preterm } \\
\text { Labour }\end{array}$ & 710.16 & 291.02 & 0.000 \\
\begin{tabular}{c} 
Premature Pregnancy \\
\hline \hline
\end{tabular} & 245.46 & 104.21 & 0.000 \\
\hline \hline
\end{tabular}

Table 1. Research Subject Characteristic

\begin{tabular}{|c|c|c|c|c|}
\hline Variabel & $\begin{array}{c}\text { Premature Gestation } \\
n(16)\end{array}$ & (\%) & $\begin{array}{l}\text { Preterm Labour } \\
\text { Threat n (16) }\end{array}$ & (\%) \\
\hline \multicolumn{5}{|l|}{ Age } \\
\hline$<20$ & 1 & 6.25 & 6 & 37.5 \\
\hline $21-24$ & 2 & 12.5 & 2 & 12.5 \\
\hline $25-29$ & 2 & 12.5 & 2 & 12.5 \\
\hline $30-35$ & 8 & 50.0 & 4 & 25.0 \\
\hline$\geq 35$ & 3 & 18.75 & 2 & 12.5 \\
\hline \multicolumn{5}{|l|}{ Parity } \\
\hline Primigravidity & 2 & 12.5 & 5 & 31.25 \\
\hline Multigravidity & 14 & 87.5 & 11 & 68.75 \\
\hline \multicolumn{5}{|l|}{ Education } \\
\hline Bachelor & 2 & 12.5 & 1 & 6.25 \\
\hline High school & 11 & 68.75 & 13 & 81.25 \\
\hline Junior High school & 3 & 18.75 & 1 & 6.25 \\
\hline Primary School & 0 & 0 & 1 & 6.25 \\
\hline \multicolumn{5}{|l|}{ Occupation } \\
\hline Employee & 6 & 37.5 & 2 & 12.5 \\
\hline Housewife / Unemployee & 10 & 62.5 & 14 & 87.5 \\
\hline \multicolumn{5}{|l|}{ Age Pregnancy } \\
\hline $28-32$ & 7 & 43.75 & 9 & 56.25 \\
\hline $32-<37$ & 9 & 56.25 & 7 & 43.75 \\
\hline
\end{tabular}




\section{DISCUSSION}

It appears that the level of sialidase on the threatened of premature labour group is higher than the sialidase levels in the premature pregnant group. Furthermore, the average level of sialidase vagina on the threatened of preterm labour group was higher than premature pregnancy group (710.16 pg / $\mathrm{ml}$ and $245.46 \mathrm{pg} / \mathrm{ml}$ ). It means that the highest value of vaginal sialidase levels in the group of the threatened of preterm labour is higher than the group of preterm pregnancy (1432.43 $\mathrm{pg} / \mathrm{ml}$ and $472.44 \mathrm{pg} / \mathrm{ml}$ ). Whilst, levels were lowest in the group threatened of preterm labour of $22.76 \mathrm{pg} / \mathrm{ml}$ and in the group of premature pregnancy $109.83 \mathrm{pg} / \mathrm{ml}$. Test normality of the data distribution vaginal sialidase levels is done by using the Shapiro-Wilk test at the significance level of 0.05 , based on the test data is normally distributed vaginal sialidase levels ( $p>0.05)$. It is seen that the levels of vaginal sialidase can also be detected in the case normally of premature pregnancy. According to the report Ann MB, et al (1992), which concluded that elevated levels of sialidase vagina were detected in 42 women (84\%) of the 50 women whose vaginal discharge containing the bacteria (bacterial vaginosis) compared to 19 women vaginal discharge does not contain bacteria / do not suffer from bacterial vaginosis $(p<0.001)$. The vaginal fluid of women who have bacterial vaginosis has sialidase levels of around $9.8 \mathrm{u}$ compared with $2.5 \mathrm{u}$ in women who do not suffer from bacterial vaginosis. And the source of the activity of this enzyme is produced by the species of Bacteroides and Prevotella in the vagina. $^{7}$

Analysis of the relationship between the vaginal sialidase levels of threatened of preterm labour groups and premature pregnancy groups was performed using the test towards variable $t$ (independent variable), it can be concluded whether there were significant differences between vaginal sialidase levels in the group with preterm pregnancy compare to the group with the threatened of premature labour. Based on a result of the test towards variable $t$, there were significant differences between the two groups, $\mathrm{p}<0.000$. So it can be concluded there is a correlation between the incidence threatened of preterm labour with vaginal sialidase levels. In this research, vaginal sialidase levels increased due to an inflammatory process that produces the vaginal sialidase enzyme on vaginal passage. In the state of infection mucus enzymes digesting enzyme produced by bacteria such as sialidase, $\beta$-Galactosidase, $\beta$-N-Acetylhexosaminidase, enzymes mucinous. Sialidase potentially lowering vaginal mucosal protective factors such as mucin, cytokines, immunoglobulins, antimicrobial molecules, and immune cell receptors. ${ }^{5}$

Howe and Wiggins reported that the levels of vaginal sialidase can be used to detect the presence of genital infections and detecting the possibility of preterm labour in pregnant women. ${ }^{6}$ Furthermore, Zang, et al (2002) compared the 80 pregnant women with bacterial vaginosis and 60 normal pregnant women at the same gestational age, then an examination of vaginal sialidase, concluded that there were significant differences between the two groups, $p<0.0001 .^{8}$ Moreover, Cauci, et al (2011) in its analysis said that an increase in vaginal sialidase levels was measured at 12 weeks of pregnancy was associated with increased incidence of premature labour and increased levels then increased the incidence of premature labour. ${ }^{5}$

In a research report; Howe, et al (1999) indicate that the mucinase activities and sialidase on vaginal microflora is an implication of the labor / threats of premature to conclude that the 31 pregnant women with vaginal infections and tests of enzyme activity hydrolase, there is increased activity of the enzyme significant enzyme sialidase in women with labor/threatened of preterm labour to the statistical test $(\mathrm{p}<0.005){ }^{6}$

The most optimal sensitivity value (93.8\%) and specificity (100\%). Above results in accordance with Bradshaw, et al (2005) in its report on the evaluation of the test in women with bacterial vaginosis using detection devices that the enzyme sialidase test tool show sensitivity at $88 \%, 95 \% \mathrm{CI}$ (81-93\%) levels, and specificity figures $95 \%, 95 \%$ CI (91-98\%) compared with conventional case. ${ }^{9}$ Whereas, the examination of Zang, et al (2002) compared the 80 pregnant women with bacterial vaginosis and 60 normal pregnant women at the same gestational age, and then examined the levels of vaginal sialidase the results of a sensitivity $96.7 \%$ and specificity of $97.5 \% .^{8}$

Cauci, et al (2011) in its research report indicate the number sialidase levels $>5 \mathrm{nmol},>10 \mathrm{nmol}$, > $14 \mathrm{nmol}$ associated with a significant incidence of early preterm birth. ${ }^{5}$ In accordance with that, Marconi, et al (2013) stated that the levels of 
sialidase vaginal bacterial vaginosis state showed the highest rate of $800 \mathrm{ng} / \mathrm{ml}^{10}{ }^{10}$ Whilst, In this research the highest number $1433.43 \mathrm{pg} / \mathrm{ml}$ $(143.343 \mathrm{ng} / \mathrm{ml})$. Sanita C, et al (2015) also reported that 35 of the total 52 pregnant patients with bacterial vaginosis were detected in the presence of enzyme activity levels of the enzyme sialidase with a median of $10.3 \mathrm{ng} / \mathrm{ml}$ (range $0.0-163.3 \mathrm{ng} / \mathrm{ml}$ ) were correlated with preterm labour and membranes ruptured. ${ }^{11}$ In this study, vaginal sialidase levels in threatened of preterm labour median result of $736.41 \mathrm{pg} / \mathrm{ml}(73.641$ $\mathrm{ng} / \mathrm{ml})$. The results of these studies support the conclusion that the bacteria associated with an enzyme that affects the mucosal barrier that can provide entry for bacteria into the reproductive tract that will cause a local infection in the birth canal.

\section{CONCLUSION}

There is a difference in meaning between the threatened of preterm labour and premature delivery group. So it can be concluded that there is a correlation between the incidence threatened of preterm labour with vaginal sialidase levels.

\section{RECOMMENDATION}

Vaginal sialidase levels may be one of the early predictors threatened of preterm labour case. It is important to do a further research with more samples and evaluation of outcomes of pregnancy also is necessary to breed the bacteria that produce the type of hydrolase enzymes in threatened of preterm labour that can be used to support the process of infection that may act as the cause of their state of prematurity.

\section{REFERENCES}

1. Honest $\mathrm{H}$, Forbes CA, Duree $\mathrm{KH}$, Norman G, Duffy SB, Tsourapas A, et al. Screening to prevent spontaneous preterm birth : systematic reviews of accuracy and effectiveness literature with economic modelling. Health Technol Assess. 2009; 13: 43.

2. Norman J, and Greer I. Preterm labour : Managing risk in clinical practice. N Engl J Med. 2006; 355: 742.

3. Kementerian Kesehatan RI. Profil Kesehatan Indonesia 2014. Yudianto, Budijanto D, Hardhana B, Soenardi TA, editors. Jakarta: Kementerian Kesehatan RI; 2015: 1-188.

4. Moutquin JM. Classification and heterogenity of preterm birth. Int Obstet Gynecol. 2003; 110(20): 30-3.

5. Cauci S, Culhane JF. High sialidase levels increase preterm birth risk among women who are bacterial vaginosis-positive in early gestation. Am J Obstet Gynecol. 2011; 204(2): 142.e1-9.

6. Howe L, Wiggins R, Soothill PW, Millar MR, Horner PJ, Corfield AP. Mucinase and sialidase activity of the vaginal microflora : implications for the pathogenesis of preterm labour. Int J STD AIDS. 1999; 10(7): 442-7.

7. Briselden AM, Moncia BJ, Stevens CE, dan Hillier SL. Sialidases (neuraminidases) in bacterial vaginosis and bacterial vaginosis-associated microflora. J Clin Microbiol. 1992; 30(3): 663-6.

8. Zhang X, Xu X, Li J, Li N, Yan T, danJu X. Relationship between vaginal sialidase bacteria vaginosis and chorioamnionitis. Zhonghua Fu Chan KeZaZhi. 2002; 37(10): 588-90.

9. Bradshaw CS, Morton AN, Garland SM, Horvath LB, Kuzevska I, dan Fairley CK. Evaluation of a Point of Care Test, BVBlue, and Clinical and Laboratory Criteria for Diagnosis of Bacterial Vaginosis. J Clin Microbiol. 2005; 43(3): 1304-8.

10. Marconi C, Donders GGG, Bellen G, Brown DR, Parada CMGL, dan Silva MG. Sialidase activity in aerobic vaginitis is equal to levels during bacterial vaginosis. Eur J Obstet Gynecol Reprod Biol. 2013; 167(2): 205-9.

11. Ferreira CS, Marconi C, Parada CM, Duarte MT, Goncalves $\mathrm{AP}$, Rudge MV, et al. Bacterial vaginosis in pregnant adolescent :pro-inflammatory cytokine and bacterial sialidase profile: cross sectional study. Sao Paulo Med J. 2015; 133(6): 465-70. 